\title{
Kajian penilaian kualitas air Sungai Bedadung di Kabupaten Jember
}

\section{Water quality assessment at Bedadung River in Jember Regency}

\author{
Elida Novita ${ }^{a}$, Hendra Andiananta Pradana ${ }^{b}$, Satria Priambada Dwija \\ a Jurusan Teknik Pertanian, Fakultas Teknologi Pertanian, Universitas Jember, 68121, Indonesia \\ ${ }^{\mathrm{b}}$ Program Studi Magister Pengelolaan Sumber Daya Air Pertanian/Alam dan Lingkungan, Pascasarjana, Universitas Jember, 68121, \\ Indonesia [+62 331-323567]
}

\section{Article Info:}

Received: 29 - 07 - 2020

Accepted: $09-12$ - 2020

Keywords:

CCME WQI, keys parameter, pollution load capacity, urban area, Water quality monitoring

Corresponding Author: Hendra Andiananta Pradana Program Studi Magister Pengelolaan Sumber Daya Air Pertanian/Alam dan Lingkungan, Pascasarjana, Universitas Jember;

Tel. +62331-323567

Email:

hendraandianantapradana@ gmail.com

\begin{abstract}
River water quality assessment plays an important role in determining the allocation of surface water resourses. The purpose of this study is to identify the pollution load capacity and the status of water quality assessment using the Canadian Council of Ministers of the Environment (CCME WQI) method. Monitoring of water quality and discharge parameters is carried out at 5 locations of water sampling. The BOD, COD, TSS, and discharge parameters in the observation period of 2019 were used to measure the value of the pollution load capacity. Water quality input data in the form of physical, chemical, and microbiological parameters in the 2016-2019 observation period were used to determine the water quality index value using the CCME WQI method. The results showed that the value of the pollution load capacity of the Bedadung River pollution in the urban area segment of Jember Regency refers to TSS, BOD, and COD parameters respectively are $17429.99 \mathrm{~kg} /$ day, $410.75 \mathrm{~kg} /$ day and $2357.33 \mathrm{~kg} /$ day. The range of Bedadung River CCME WQI values for the Urban segment of Jember Regency from 2016-2019 is 53.21-79.31 category fair to marginal categories. The parameters that cause low CCME WQI values are $\mathrm{BOD}, \mathrm{COD}, \mathrm{H}_{2} \mathrm{~S}, \mathrm{Cl}-, \mathrm{PO}_{4}$, and total coliform.
\end{abstract}

How to cite (CSE Style $8^{\text {th }}$ Edition):

Novita E, Pradana HA, Dwija SP. 2020. Kajian penilaian kualitas air Sungai Bedadung di Kabupaten Jember. JPSL 10(4): 699-714. http://dx.doi.org/10.29244/jpsl.10.4.699-714.

\section{PENDAHULUAN}

Keberadaan sumber air berperan vital dalam kehidupan manusia. Akan tetapi sumber daya air di beberapa wilayah dalam kondisi yang tidak layak dimanfaatkan sebagai sumber air baku. Abbaspour (2011) melaporkan bahwa penurunan kualitas air menjadi isu-isu prioritas di negera berkembang. Penurunan kualitas sumber air permukaan merupakan akibat dari tekanan pencemaran dari rendahnya upaya sanitasi lingkungan dan instalasi penanganan air limbah (Dwivedi, 2017; Yustiani et al., 2018). Fenomena tersebut juga dialami di Negara Indonesia. Terdapat 44 sungai di Indonesia seperti Sungai Musi, Citarum, Ciliwung, Brantas, dan Barito memiliki nilai kualitas air yang tidak memenuhi baku mutu kelas II (Yetti et al., 2011; Asian Development Bank, 2016; Yudo dan Said, 2018).

Daerah Aliran Sungai (DAS) Bedadung memiliki beberapa sungai besar. Salah satu sungai tersebut merupakan Sungai Bedadung yang melintasi Pusat Kegiatan Wilayah atau Wilayah Perkotaan Kabupaten Jember yang meliputi Kecamatan Patrang, Sumbersari, dan Kaliwates (Peraturan Daerah Kabupaten Jember 
Nomor 1 Tahun 2015). Sungai Bedadung dimanfaatkan sebagai salah satu sumber air baku oleh Perumdam Tirta Pandalungan Kabupaten Jember. Lokasi water intake Perumdam Tirta Pandalungan Kabupaten Jember terletak di Kecamatan Patrang dan Kaliwates. Dinamika di DAS Bedadung bepengaruh terhadap kualitas air Sungai Bedadung. Akumulasi beban pencemaran Biochemical Oxygen Demand (BOD) dari segmen Kecamatan Patrang-Sumbersari berpotensi menurunkan kualitas air Sungai Bedadung (Pradana et al., 2019a). Sementara itu, hasil identifikasi nilai Chemical Oxygen Demand (COD) di water intake Instalasi Pengolahan Air (IPA) Tegal Besar yang berada di Kecamatan Kaliwates tidak memenuhi baku mutu kelas I (Pradana et al., 2019b). Fenomena ini akan mengancam penyediaan sumber air baku di Wilayah Perkotaan Kabupaten Jember. Oleh sebab itu diperlukan upaya pengelolaan sumber air. Merujuk pada Peraturan Pemerintah Republik Indonesia Nomor 82 Tahun 2001 pemantauan kualitas air sungai merupakan salah satu bagian dari pengelolaan kualitas air dan pengendalian pencemaran sumber air.

Pemantauan beberapa parameter kualitas air dapat digunakan untuk mengevaluasi dan menilai kondisi status mutu air sungai guna pertimbangan peruntukannya. Evaluasi kualitas air Sungai Bedadung dan anak sungainya yang melewati segmen perkotaan di Kabupaten Jember pada periode pengamatan tahun 2018-2019 hanya berdasarkan parameter BOD, debit, COD, dan beban pencemaran (Aziza et al., 2018; Pradana et al., 2019a). Kondisi ini kurang mencerminkan kondisi air Sungai Bedadung, mengingat cukup banyak parameter kualitas air (fisika, kimia, dan mikrobiologi) yang perlu diamati dan dievaluasi untuk dapat menilai kondisi kualitas air secara lebih baik. Penilaian status mutu air dapat dilakukan dengan beberapa metode yaitu Indeks Pencemaran dan Storet (Keputusan Menteri Negara Lingkungan Hidup Nomor 115 Tahun 2003), akan tetapi aplikasi metode Indeks Kualitas Air (IKA) atau CCME WQI yang diterbitkan oleh Kementrian Lingkungan Hidup Negara Kanada dapat diasumsikan lebih mampu mencerminkan kondisi kualitas air sesuai peruntukannya daripada metode Indeks Pencemaran dan Storet (Saraswati et al., 2014; Haeruddin et al., 2019; Saraswati et al., 2019).

Secara umum metode IKA mempertimbangkan keberadaan bahan pencemar dan baku mutu peruntukannya dan dapat digunakan pada input data majemuk. Adapun beberapa metode IKA yang sudah diaplikasi di beberapa wilayah yaitu Horton Model, National Sanitation Foundation Water Quality Index (NFSWQI), Oregon Water Quality Index (OWQI), Canada Council Ministers of the Environment Water Quality Index (CCMEWQI), dan Global Drinking Water Quality Index (GDWQI) (Lumb et al., 2011; Tallar dan Suen, 2015; Poonam et al., 2015; Hussein dan Ali, 2017; Piranti et al., 2018). CCME WQI menjadi salah satu metode yang memiliki sensitivitas yang relatif baik dalam merefleksikan kondisi kualitas perairan tropis di Indonesia (Saraswati et al., 2014). Tujuan dari penelitian ini yaitu mengidentifikasi daya tampung beban pencemaran berdasarkan parameter BOD, COD, dan TSS serta menilai status mutu air sungai menggunakan metode CCME WQI di Sungai Bedadung yang melewati segmen Pusat Kegiatan Wilayah Kabupaten Jember. Kajian ini dapat digunakan sebagai pertimbangan penentuan daya tampung beban pencemaran dan status mutu air Sungai Bedadung segmen Perkotaan Kabupaten Jember guna pengendalian sumber pencemaran dan pengelolaan kualitas sumber daya air permukaan.

\section{METODE}

\section{Lokasi dan Waktu Penelitian}

Pengambilan contoh air dilakukan di Sungai Bedadung yang melewati Kecamatan Patrang, Sumbersari, dan Kaliwates dengan spesifikasi lokasi yang dapat dilihat pada Tabel 1 dan Gambar 1. Pada segmen tersebut terdapat 2 water intake Perumdam Tirta Pandalungan Kabupaten Jember yaitu Instalasi Pengolahan Air (IPA) Tegal Gede Kecamatan Patrang dan Tegal Besar Kecamatan Kaliwates (Pradana et al., 2019b). Yaitu berada pada antara titik pertama dan kedua serta berada pada titik keempat dan kelima. 
Pengumpulan data contoh air dengan metode grab sampling dilakukan pada tanggal 19 Mei sampai dengan 19 Oktober 2019 dengan pengulangan tiga kali. Data tersebut merupakan data primer yang diuji di Laboratorium PT Sucofindo Surabaya yang sudah diakreditas oleh Komite Akreditasi Nasional (KAN). Adapun data sekunder berupa kualitas air Sungai Bedadung pada tahun 2016 sampai 2018 diperoleh dari Dinas Lingkungan Hidup Kabupaten Jember. Waktu pengambilan data dan pengujian dapat dilihat pada Tabel 2. Metode standar pengujian kualitas air sungai berdasarkan 28 parameter fisik, kimia, dan mikrobiologi pada Tabel 3. Penggunaan kelas mutu menggunakan baku mutu kelas I merujuk pada Peraturan Pemerintah Republik Indonesia Nomor 82 Tahun 2001.

Tabel 1 Lokasi pengambilan contoh air 2016-2019

\begin{tabular}{clcccc}
\hline \multirow{2}{*}{ Titik } & \multirow{2}{*}{ Lokasi } & \multirow{2}{*}{ Desa } & \multirow{2}{*}{ Kecamatan } & \multicolumn{2}{c}{ Koordinat } \\
& & & & Longitude & Latitude \\
\hline 1 & Jl Slamet Riyadi & Patrang & Patrang & 113.7256520 & -8.1497490 \\
2 & J1 Mastrip & Sumbersari & Sumbersari & 113.7121370 & -8.1570250 \\
3 & J1 Bengawan Solo & Sumbersari & Sumbersari & 113.7068930 & -8.1547150 \\
4 & J1 Sumatera & Sumbersari & Sumbersari & 113.7056960 & -8.1763930 \\
5 & J1 Imam Bonjol & Kaliwates & Kaliwates & 113.6833410 & -8.1863103 \\
\hline
\end{tabular}

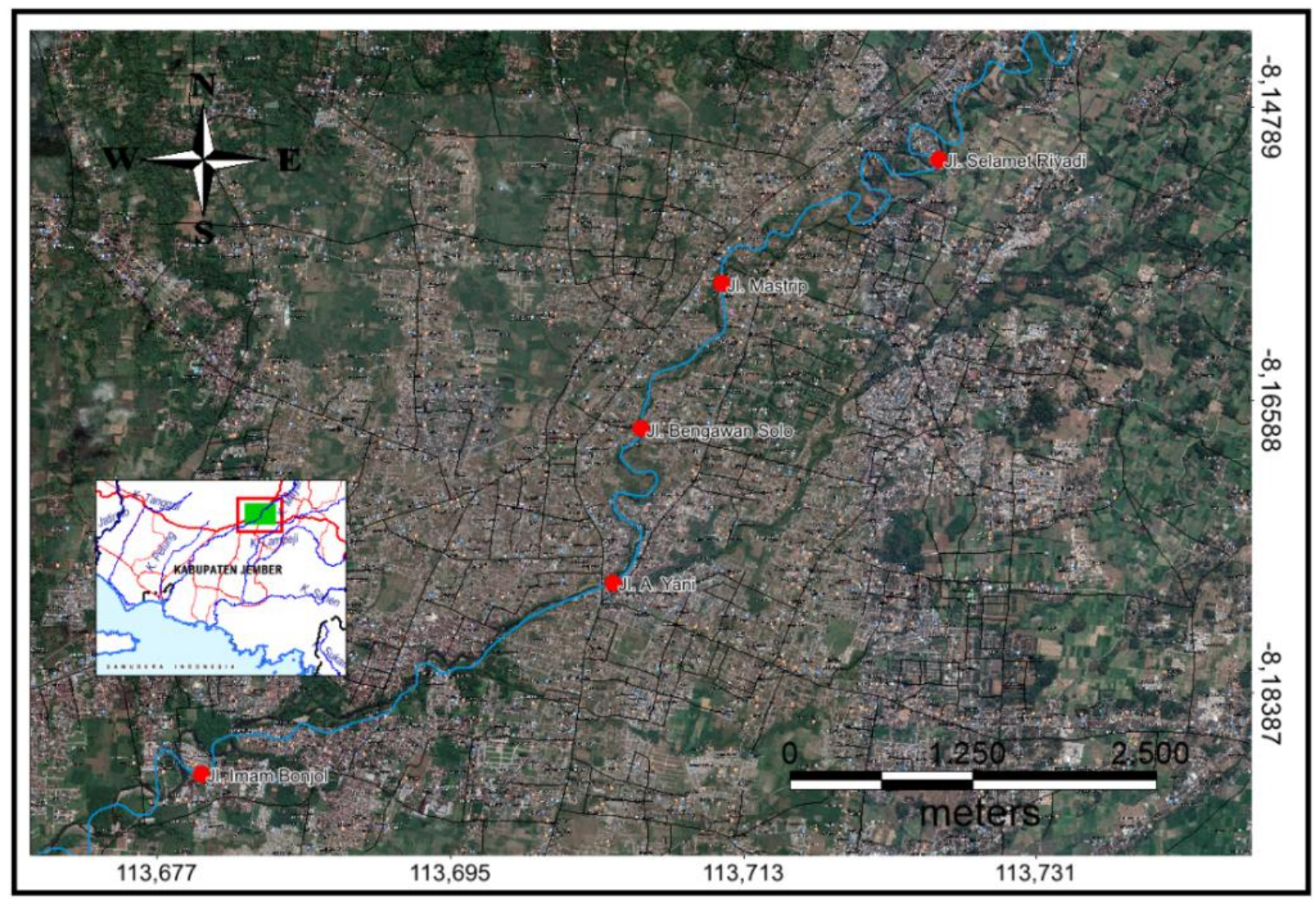

Gambar 1 Peta lokasi lima titik pengambilan contoh air Sungai Bedadung di segmen Kecamatan Patrang, Sumbersari dan Kaliwates Kabupaten Jember 
Tabel 2 Waktu pengambilan sampel dan pengujian CCME WQI tahun 2016-2019

\begin{tabular}{|c|c|c|c|c|c|}
\hline Lokasi & $\begin{array}{c}\text { Waktu } \\
\text { Penelitian }\end{array}$ & $2016^{1}$ & $2017^{1}$ & $2018^{1}$ & $2019^{1}$ \\
\hline \multirow{10}{*}{$\begin{array}{l}\text { Jl.Slamet } \\
\text { Riyadi }\end{array}$} & Periode $\left.1^{*}\right)$ & & & & \\
\hline & Tanggal & - & 10-11 Juni & - & 19-20 Mei \\
\hline & Sampling & & & & \\
\hline & Tanggal & & 12 Juni-7 Juli & & $20 \mathrm{Mei}-17$ \\
\hline & Pengujian & & & & Juni \\
\hline & Periode $\left.2^{* *}\right)$ & & & & \\
\hline & Tanggal & 7-8 November & $25-26$ & 23-24 Oktober & - \\
\hline & Sampling & & September & & \\
\hline & Tanggal & 14 November-1 & 2 - 19 Oktober & 24 Oktober-12 & \\
\hline & Pengujian & Desember & & November & \\
\hline \multirow{8}{*}{$\begin{array}{l}\text { Jl. } \\
\text { Mastrip }\end{array}$} & Periode $\left.1^{*}\right)$ & & & & \\
\hline & $\begin{array}{l}\text { Tanggal } \\
\text { Sampling }\end{array}$ & - & 10-11 Juni & - & 19-20 Mei \\
\hline & Tanggal & & 12 Juni-7 Juli & & $20 \mathrm{Mei}-17$ \\
\hline & Pengujian & & & & Juni \\
\hline & Periode $2^{* *}$ & & & & \\
\hline & $\begin{array}{l}\text { Tanggal } \\
\text { Sampling }\end{array}$ & 7-8 November & - & 23-24 Oktober & - \\
\hline & Tanggal & 14 November-1 & & 24 Oktober-12 & \\
\hline & Pengujian & Desember & & November & \\
\hline \multirow{9}{*}{$\begin{array}{l}\text { Jl. } \\
\text { Bengawa } \\
\text { n Solo }\end{array}$} & Periode $\left.1^{*}\right)$ & & & & \\
\hline & Tanggal & 23-24 Mei & 10-11 Juni & - & 19-20 Mei \\
\hline & Sampling & 24 Mi 11 Juni & & & $20 \mathrm{M} \cdot 17$ \\
\hline & Tanggal & 24 Mei-11 Juni & 12 Juni-7 Juli & & $20 \mathrm{Mei}-17$ \\
\hline & $\begin{array}{l}\text { Pengujian } \\
\left.\text { Periode } 2^{* *}\right)\end{array}$ & & & & \\
\hline & Tanggal & 7-8 November & $25-26$ & 23-24 Oktober & - \\
\hline & Sampling & & September & & \\
\hline & Tanggal & 14 November-1 & 2-19 Oktober & 24 Oktober-12 & \\
\hline & Pengujian & Desember & & November & \\
\hline \multirow{9}{*}{$\begin{array}{l}\text { Jl. } \\
\text { Sumatera }\end{array}$} & Periode $\left.1^{*}\right)$ & & & & \\
\hline & $\begin{array}{l}\text { Tanggal } \\
\text { Sampling }\end{array}$ & - & - & - & 19-20 Mei \\
\hline & Tanggal & & & & 20 Mei-17 \\
\hline & Pengujian & & & & Juni \\
\hline & Periode $\left.2^{* *}\right)$ & & & & \\
\hline & Tanggal & 7-8 November & $25-26$ & 23-24 Oktober & - \\
\hline & Sampling & & September & & \\
\hline & Tanggal & 14 November-1 & 2-19 Oktober & 24 Oktober-12 & \\
\hline & Pengujian & Desember & & November & \\
\hline \multirow{9}{*}{$\begin{array}{l}\text { Jl. Imam } \\
\text { Bonjol }\end{array}$} & Periode $\left.1^{*}\right)$ & & & & \\
\hline & $\begin{array}{l}\text { Tanggal } \\
\text { Sampling }\end{array}$ & 23-24 Mei & 10-11 Juni & 25-26 Juni & 19-20 Mei \\
\hline & Tanggal & 14 November-1 & 12 Juni-7 Juli & 26 Juni-16 Juli & $20 \mathrm{Mei}-17$ \\
\hline & Pengujian & Desember & & & Juni \\
\hline & Periode $2^{* * *}$ & & & & \\
\hline & Tanggal & 7-8 November & $25-26$ & 23-24 Oktober & - \\
\hline & Sampling & & September & & \\
\hline & Tanggal & 14 November- 1 & 2-19 Oktober & 24 Oktober-12 & \\
\hline & Pengujian & Desember & & November & \\
\hline
\end{tabular}

Keterangan: Sumber data 1. Dinas Lingkungan Hidup Kabupaten Jember; 2. data primer (grab sampling); *) periode 1, merupakan data diambil pada saat musim kemarau; **) periode 2, merupakan data diambil pada saat musim penghujan 


\section{Metode Pengumpulan Data}

Materi yang digunakan untuk penelitian ini merupakan contoh air yang diperoleh dari Sungai Bedadung, dengan metode standar uji pada Tabel 3. Lokasi pengambilan contoh air dimanfaatkan sebagai sumber air baku sehingga baku mutu pembandingnya menggunakan baku mutu Kelas 1 (Pradana et al., (2019b). Prosedur pengambilan contoh air merujuk pada Standar Nasional Indonesia (SNI) Nomor 06-7016-2004. Spesifikasi parameter dan metode pengujian contoh air pada periode pengamatan 2016-2019 berdasarkan metode standar (APHA et al., 2012; APHA et al., 2017). Pengambilan sampel dilakukan menggunakan botol yang bervolume 5 Liter dan dimasukkan ke coolbox berisikan es batu sebagai bentuk pengawetan sampel selama pengambilan sampel menuju lab pengujian kualitas air. Contoh air tersebut diambil dari 5 titik pemantauan dan diangkut ke PT Sucofindo Surabaya untuk diuji. Data sekunder diperoleh dari Dinas Lingkungan Hidup Jember sebagai data pendukung untuk menambah tingkat keakuratan status mutu Sungai Bedadung.

Tabel 3 Parameter kualitas air sungai dan metode pengujiannya

\begin{tabular}{|c|c|c|c|c|c|c|c|}
\hline No & Parameter & Satuan & $\begin{array}{l}\text { Baku } \\
\text { Mutu I } \\
*)\end{array}$ & $\begin{array}{l}\text { Metode Standar } \\
\left.\text { Tahun } 2016^{* * *}\right)\end{array}$ & $\begin{array}{l}\text { Metode Standar } \\
\text { Tahun } 2017^{* * *}\end{array}$ & $\begin{array}{l}\text { Metode Standar } \\
\left.\text { Tahun } 2018^{* *}\right)\end{array}$ & $\begin{array}{l}\text { Metode Standar } \\
\left.\text { Tahun } 2019^{* *}\right)\end{array}$ \\
\hline 1 & Suhu & ${ }^{\circ} \mathrm{C}$ & $\begin{array}{c}\text { Deviasi } \\
3\end{array}$ & IKM/5.4.97/MB & $\begin{array}{l}\text { SNI 06-6989.23- } \\
2005\end{array}$ & $\begin{array}{c}\text { SNI 06-6989 23- } \\
2005\end{array}$ & $\begin{array}{l}\text { APHA } 2550 \mathrm{~B} \\
2017\end{array}$ \\
\hline 2 & TDS & $\mathrm{mg} / \mathrm{L}$ & 1000 & IKM/5.4.95/MB & $\mathrm{IKM} / 5.4 .95 / \mathrm{MB}$ & IKM/5.4.76/MBS & $\begin{array}{c}\text { APHA } 2540 \mathrm{C} \\
2017\end{array}$ \\
\hline 3 & TSS & $\mathrm{mg} / \mathrm{L}$ & 50 & $\begin{array}{c}\text { APHA } 2540 \mathrm{D} \\
2005\end{array}$ & $\begin{array}{c}\text { APHA } 2540 \text { D } \\
2012\end{array}$ & $\begin{array}{c}\text { APHA } 2540 \text { D } \\
2017\end{array}$ & $\begin{array}{c}\text { APHA } 2540 \text { D } \\
2017\end{array}$ \\
\hline 4 & $\mathrm{pH}$ & - & $6-9$ & $\begin{array}{l}\text { APHA } 4500 \mathrm{H}+ \\
2005\end{array}$ & $\begin{array}{c}\text { SNI 06-6989.11- } \\
2004\end{array}$ & SNI 6989112004 & $\begin{array}{l}\text { APHA 4500- } \\
\text { H+-B } 2017\end{array}$ \\
\hline 5 & COD & $\mathrm{mg} / \mathrm{L}$ & 10 & SNI 6989.73.2009 & SNI 6989.73.2009 & SNI 6989733009 & $\begin{array}{c}\text { APHA } 5220 \text { B } \\
2017\end{array}$ \\
\hline 6 & BOD & $\mathrm{mg} / \mathrm{L}$ & 2 & IKM/5.4.112/MB & $\mathrm{IKM} / 5.4 .112 / \mathrm{MB}$ & IKM/7.2.112/MB & $\begin{array}{c}\text { APHA } 5210 \text { B } \\
2017\end{array}$ \\
\hline 7 & DO & $\mathrm{mg} / \mathrm{L}$ & 6 & IKM/5.4.97/MB & IKM/5.4.97/MB & IKM/7.2.97/MB & $\begin{array}{l}\text { APHA 4500-O } \\
\quad \text { B } 2017\end{array}$ \\
\hline 8 & $\begin{array}{l}\text { Amonia } \\
\text { Bebas } \\
\left(\mathrm{NH}_{3}-\mathrm{N}\right)\end{array}$ & $\mathrm{mg} / \mathrm{L}$ & 1 & $\begin{array}{l}\text { APHA } 4500 \mathrm{NH} 3+ \\
2005\end{array}$ & $\begin{array}{c}\text { APHA } 4500 \text { NH3+ } \\
2005\end{array}$ & $\begin{array}{c}\text { APHA } 4500 \mathrm{NH} 2 \\
2017\end{array}$ & $\begin{array}{l}\text { APHA 4500- } \\
\mathrm{NH}_{3}-\mathrm{F} 2017\end{array}$ \\
\hline 9 & Kobalt (Co) & $\mathrm{mg} / \mathrm{L}$ & 0 & $\begin{array}{c}\text { SNI 06-6989.68- } \\
2009\end{array}$ & $\begin{array}{c}\text { SNI 06-6989.68- } \\
2009\end{array}$ & $\begin{array}{c}\text { SNI } 0698968 \\
2009\end{array}$ & $\begin{array}{c}\text { APHA } 3120 \text { B } \\
2017\end{array}$ \\
\hline 10 & $\begin{array}{l}\text { Kadmium } \\
(\mathrm{Cd})\end{array}$ & $\mathrm{mg} / \mathrm{L}$ & 0 & $\begin{array}{l}\text { APHA } 3111 \text { B } \\
2005\end{array}$ & $\begin{array}{l}\text { APHA } 3111 \text { B } \\
2005\end{array}$ & SNI 6989.16-2009 & $\begin{array}{c}\text { APHA } 3120 \text { B } \\
2017\end{array}$ \\
\hline 11 & $\begin{array}{l}\text { Tembaga } \\
(\mathrm{Cu})\end{array}$ & $\mathrm{mg} / \mathrm{L}$ & 0 & $\begin{array}{c}\text { SNI 06- } \\
\text { 6989.6.2009 }\end{array}$ & $\begin{array}{c}\text { SNI 06- } \\
\text { 6989.6.2009 }\end{array}$ & $\begin{array}{c}\text { SNI 06-6989 } 6 \\
2009\end{array}$ & $\begin{array}{c}\text { APHA } 3120 \text { B } \\
2017\end{array}$ \\
\hline 12 & Seng $(\mathrm{Zn})$ & $\mathrm{mg} / \mathrm{L}$ & 0 & $\begin{array}{c}\text { SNI 06- } \\
\text { 6989.7.2009 }\end{array}$ & $\begin{array}{c}\text { SNI 06- } \\
\text { 6989.7.2009 }\end{array}$ & SNI 698972009 & $\begin{array}{c}\text { APHA } 3120 \text { B } \\
2017\end{array}$ \\
\hline 13 & $\begin{array}{l}\text { Sulfida } \\
\left(\mathrm{H}_{2} \mathrm{~S}\right)\end{array}$ & $\mathrm{mg} / \mathrm{L}$ & 0 & IKM/5.4.109/MB & $\mathrm{IKM} / 5.4 .109 / \mathrm{MB}$ & IKM/7.2.109/MB & $\begin{array}{l}\text { APHA 4500- } \\
\text { S2-D } 2017\end{array}$ \\
\hline 14 & Klor $\left(\mathrm{Cl}^{-}\right)$ & $\mathrm{mg} / \mathrm{L}$ & 1 & $\begin{array}{l}\text { APHA } 4500 \mathrm{Cl}- \\
2005\end{array}$ & IKM/5.4.74/MBS & SNI 6989122009 & $\begin{array}{l}\text { APHA 4500-Cl } \\
\text { B } 2017\end{array}$ \\
\hline 15 & Sulfat $\left(\mathrm{SO}_{4}\right)$ & $\mathrm{mg} / \mathrm{L}$ & 400 & IKM/5.4.108/MB & IKM/5.4.64/MBS & IKM/5.4.64/MBS & $\begin{array}{l}\text { APHA 4500- } \\
\text { SO4 2-E } 2017\end{array}$ \\
\hline 16 & $\begin{array}{l}\text { Minyak dan } \\
\text { Lemak }\end{array}$ & $\mu \mathrm{g} / \mathrm{L}$ & 1000 & APHA 5520 B2005 & $\begin{array}{l}\text { APHA Section } \\
5520 \text { B } 2005\end{array}$ & SNI 6989 10-2011 & $\begin{array}{l}\text { APHA } 5520 \text { B } \\
2017\end{array}$ \\
\hline 17 & MBAS & $\mu \mathrm{g} / \mathrm{L}$ & 200 & $\begin{array}{c}\text { SNI 06- } \\
6989.51 .2009\end{array}$ & SNI 6989.51.2005 & $\begin{array}{l}\text { SNI } 06698951- \\
\quad 2005\end{array}$ & $\begin{array}{c}\text { APHA } 5540 \mathrm{C} \\
2017\end{array}$ \\
\hline 18 & Fenol & $\mathrm{mg} / \mathrm{L}$ & 1 & IKM/5.4.107/MB & IKM/5.4.107/MB & $\mathrm{IKM} / 7.2 .107 / \mathrm{MB}$ & $\begin{array}{c}\text { APHA } 5530 \mathrm{C} \\
2017\end{array}$ \\
\hline 19 & $\begin{array}{l}\text { Nitrit }\left(\mathrm{NO}_{2-}\right. \\
\mathrm{N})\end{array}$ & $\mathrm{mg} / \mathrm{L}$ & 0 & IKM/5.4.110/MB & IKM/5.4.110/MB & IKM/7.2.110/MB & $\begin{array}{l}\text { APHA 500- } \\
\text { NO2- B } 2017\end{array}$ \\
\hline 20 & $\operatorname{Besi}(\mathrm{Fe})$ & $\mathrm{mg} / \mathrm{L}$ & 0 & Skeptrofotometer & Skeptrofotometer & IKM/5.4 57/MBS & $\begin{array}{l}\text { APHA } 3120 \text { B } \\
2017\end{array}$ \\
\hline 21 & Timbal $(\mathrm{Pb})$ & $\mathrm{mg} / \mathrm{L}$ & 0 & $\begin{array}{l}\text { APHA 3111- B } \\
\quad 2005\end{array}$ & IKM/5.4.77/MBS & SNI 6989 2-2009 & $\begin{array}{c}\text { APHA } 3120 \text { B } \\
2017\end{array}$ \\
\hline 22 & Florida (F) & $\mathrm{mg} / \mathrm{L}$ & 1 & Skeptrofotometer & IKM/5.4.61/MBS & IKM/5.4 61/MBS & $\begin{array}{c}\text { APHA 4500-F - } \\
\text { D } 2017\end{array}$ \\
\hline
\end{tabular}




\begin{tabular}{|c|c|c|c|c|c|c|c|}
\hline No & Parameter & Satuan & $\begin{array}{l}\text { Baku } \\
\text { Mutu I } \\
*)\end{array}$ & $\begin{array}{l}\text { Metode Standar } \\
\text { Tahun } 2016^{* *)}\end{array}$ & $\begin{array}{l}\text { Metode Standar } \\
\left.\text { Tahun } 2017^{* *}\right)\end{array}$ & $\begin{array}{l}\text { Metode Standar } \\
\left.\text { Tahun } 2018^{* *}\right)\end{array}$ & $\begin{array}{c}\text { Metode Standar } \\
\left.\text { Tahun } 2019^{* *}\right)\end{array}$ \\
\hline 23 & $\begin{array}{l}\text { Klorin } \\
\text { Bebas }\left(\mathrm{Cl}_{2}\right)\end{array}$ & $\mathrm{mg} / \mathrm{L}$ & 0 & Skeptrofotometer & IKM/5.4.52/MBS & IKM/5.4.52/MBS & $\begin{array}{l}\text { APHA 4500- } \\
\mathrm{Cl}_{2}-\mathrm{B} 2017\end{array}$ \\
\hline 24 & $\begin{array}{l}\text { Nitrat }\left(\mathrm{NO}_{3-}\right. \\
\mathrm{N})\end{array}$ & $\mathrm{mg} / \mathrm{L}$ & 10 & Skeptrofotometer & IKM/5.4.65/MBS & IKM/5.4.65/MBS & $\begin{array}{l}\text { APHA 4500- } \\
\text { NO3-E } 2017\end{array}$ \\
\hline 25 & $\begin{array}{l}\text { Pospat } \\
\left(\mathrm{PO}_{4}\right)\end{array}$ & $\mathrm{mg} / \mathrm{L}$ & 0 & $\begin{array}{c}\text { SNI 06- } \\
\text { 6989.31.2004 }\end{array}$ & Skeptrofotometer & IKM/5.4.70/MBS & $\begin{array}{l}\text { APHA 4500-P } \\
\quad \text { C } 2017\end{array}$ \\
\hline 26 & $\begin{array}{l}\text { Mangan } \\
(\mathrm{Mn})\end{array}$ & $\mathrm{mg} / \mathrm{L}$ & 1 & Skeptrofotometer & Skeptrofotometer & SNI 6989.5-2009 & $\begin{array}{c}\text { APHA } 3120 \text { B } \\
2017\end{array}$ \\
\hline 27 & $\begin{array}{l}\text { Kromium } \\
\text { Hexavalen }\end{array}$ & $\mathrm{mg} / \mathrm{L}$ & 0 & Skeptrofotometer & Skeptrofotometer & IKM/5.4 54/MBS & $\begin{array}{l}\text { APHA 3500-Cr- } \\
\text { B } 2017\end{array}$ \\
\hline 28 & $\begin{array}{l}\text { Total } \\
\text { Coliform }\end{array}$ & $\begin{array}{l}\mathrm{MPN} / 100 \\
\mathrm{~mL}\end{array}$ & 1000 & Tabung Ganda & IKM/5.4.87/MBS & $\begin{array}{c}\text { IKM/5.4 87/MBS } \\
(\mathrm{MPN})\end{array}$ & $\begin{array}{c}\text { APHA } 9221 \text { B \# } \\
2012\end{array}$ \\
\hline
\end{tabular}

Keterangan: *) Baku mutu air kelas I, Peraturan Pemerintah Republik Indonesia Nomor 82 Tahun 2001;

**) American Public Health Association (APHA) 2005, (APHA) 2012, APHA (2017), Standar Nasional Indonesia (SNI)

\section{Metode Analisis Data}

\section{Beban Pencemaran dan Daya Tampung Beban Pencemaran}

Nilai beban pencemaran dipengaruhi oleh nilai debit dan konsentrasi parameter kualitas air. Pengukuran debit dilakukan pada setiap pias cross section pada masing-masing lokasi pengamatan. Pembagian pias berdasarkan relief pada cross section (Tanika et al., 2016). Pias merupakan pembagian penampang suatu saluran atau sungai secara melintang. Setiap current meter memiliki rumus kalibrasi untuk menentukan kecepatan aliran yang ditunjukkan pada Persamaan 1. Debit yang dicatat merupakan total debit dari semua pias yang diperoleh berdasarkan perkalian antara kecepatan aliran dan luas penampang pada masing-masing pias. Berikut merupakan perhitungan debit total yang dapat dilihat pada Persamaan 2 (Pradana et al., 2019a).

Keterangan:

$$
\mathrm{V}=\mathrm{aN}+\mathrm{b}
$$

$\mathrm{V}=$ Kecepatan aliran air (m/detik)

$\mathrm{a} \& \mathrm{~b}=$ Konstanta current meter (Merk Seba Hydrometry Universal Current Meter F1)

$\mathrm{N} \quad=$ Jumlah putaran baling-baling (putaran/detik)

$$
\mathrm{Q}=\mathrm{L} 1 \mathrm{D} 1 \mathrm{~V} 1+\mathrm{L} 2 \mathrm{D} 2 \mathrm{~V} 2+\mathrm{L} 3 \mathrm{D} 3 \mathrm{~V} 3 \ldots \ldots \mathrm{LnDnVn}
$$

Keterangan:

$\mathrm{Q}=$ Debit $\left(\mathrm{m}^{3} /\right.$ detik $)$

$\mathrm{D}=$ Kedalaman $(\mathrm{m})$

$\mathrm{L}=$ Lebar Interval (m)

$\mathrm{V}=$ Kecepatan rata-rata pada tiap pias kedalaman pengukuran $(\mathrm{m} /$ detik)

Beban pencemaran merupakan jumlah suatu unsur pencemar yang terkandung dalam air atau limbah (Peraturan Pemerintah Republik Indonesia Nomor 82 tahun 2001). Nilai beban pencemaran dapat diketahui dengan mengalikan konsentrasi bahan pencemar, debit air, dan faktor konversi. Merujuk pada Lampiran II Peraturan Menteri Negara Lingkungan Hidup Nomor 1 (2010), formula untuk menghitung nilai beban pencemaran dapat dilihat pada persamaan 3. Pemilihan parameter kualitas air berupa TSS, BOD, dan COD yang digunakan untuk mengukur nilai beban pencemaran berdasarkan parameter kunci pada Program Kali Bersih (Peraturan Menteri Negara Lingkungan Hidup Nomor 1, 2010). 
Keterangan:

$$
B P=Q \times C \times f
$$

$\mathrm{BP}=$ Beban pencemaran sungai $(\mathrm{kg} / \mathrm{hari})$

$\mathrm{Q}=$ Debit air sungai $\left(\mathrm{m}^{3} /\right.$ detik $)$

$\mathrm{C}=$ Konsentrasi TSS, BOD, dan COD $(\mathrm{mg} / \mathrm{L})$

$f=$ Faktor konversi satuan $=0.0864$ (kg.liter.detik) $/\left(\mathrm{mg} . \mathrm{m}^{3} / \mathrm{hari}\right)$

Penentuan Daya Tampung Beban Pencemaran (DTBP) Sungai Bedadung berdasarkan kemampuan sungai dalam menerima bahan pencemar yang tidak melebihi baku mutu sesuai peruntukannya. Baku mutu yang digunakan pada penelitian ini adalah baku mutu Kelas I untuk sumber air bersih atau domestik sesuai dengan PP nomor 82 Tahun 2001. Berikut ini merupakan persamaan penentuan daya tampung beban pencemaran sungai (Djoharam et al., 2018).

Keterangan:

$$
D T B P=B P_{\min }-B P_{\text {terukur }}
$$

DTBP = Daya tampung beban pencemaran $(\mathrm{kg} / \mathrm{hari})$

$\mathrm{BP}_{\min }=$ Beban pencemaran sesuai baku mutu $(\mathrm{kg} / \mathrm{hari})$

$\mathrm{BP}_{\text {terukur }}=$ Beban pencemaran yang terukur $(\mathrm{kg} / \mathrm{hari})$

\section{Evaluasi Kualitas Air Sungai}

Penilaian kualitas air dapat dilakukan secara deskriptif kuantitatif. Pendekatan tersebut dapat ditempuh dengan cara membandingkan parameter kualitas air dengan baku mutu (Sahabuddin et al., 2014; Effendi, 2016; Yudo dan Said, 2018). Baku mutu kualitas air yang digunakan untuk membandingkan beberapa parameter kualitas air adalah baku mutu air Kelas I. Penentuan ini berdasarkan pemanfaatan Sungai Bedadung sebagai sumber air baku untuk air minum bagi Perumdam Tirta Pandalungan Kabupaten Jember (Pradana et al., 2019a; Pradana et al., 2019b).

\section{Perhitungan Indeks Kualitas Air}

Penggunaan metode CCME-WQI menghasilkan status mutu air yang lebih mencerminkan kondisi sebenarnya daripada nilai Indeks Pencemaran (IP) dan Storet serta cukup mudah diaplikasikan (Saraswati et al., 2014; Jafarabadi et al., 2016). Metode ini juga memiliki tingkat efektivitas dan sensitivitas yang lebih tinggi dibandingkan dengan metode IP dan Storet (Romdania et al., 2018). CCME WQI juga menggunakan data pengulangan waktu (time series data) sehingga menggambarkan kondisi lingkungan yang sebenarnya dalam kurun waktu tertentu, tetapi CCME WQI juga memiliki perhitungan yang lebih komplek dibandingkan metode IP dan Storet (Romdania et al., 2018). CCME WQI merupakan salah satu metode pengukuran indeks kualitas air dari British Colombia pada pertengahan 1990-an (Canadian Council of Ministers of the Environment, 2001). Pendekatan pada metode tersebut berdasarkan pada nilai perhitungan frekuensi yang berasal dari parameter yang telah menyimpang dari baku mutu sesuai peruntukannya (Kachroud et al., 2019). Hasil perhitungan nilai CCME WQI dapat dikategorikan berdasarkan Tabel 3. Berikut adalah tahapan perhitungan CCME WQI (Lumb et al., 2011).

1. F1 (Scope), menyatakan persentase variabel-variabel yang menyimpang dari baku mutu yang telah ditetapkan. Formula dari F1 dapat dilihat pada persamaan 5.

$$
\mathrm{F} 1=\frac{\text { Jumlah } \text { variabel menyimpang }}{\text { Total jumlah variabel }} \times 100 \%
$$

2. F2 (Frequency), menyatakan persentase uji setiap parameter yang tidak memenuhi baku mutu. Formula dari F2 dapat dilihat pada persamaan 6. 
Novita E, Pradana HA, Dwija SP

$$
\mathrm{F} 2=\frac{\text { Jumlah pengujian menyimpang }}{\text { Total jumlah pengujian }} \times 100 \%
$$

3. F3 (Amplitude), menyatakan jumlah nilai penyimpangan. Formula dari F3 dapat dilihat pada persamaan 7.

$$
\mathrm{F} 3=\frac{n s e}{0,01 n s e+0,01}
$$

Keterangan: nse merukapakan total nilai penyimpangan setiap pengujian yang dapat dilihat pada persamaan 8 .

$$
\text { Rumus } n s e=\frac{\sum_{i=0}^{n} \frac{\text { Nilai uji yang menyimpang }}{\text { Baku mutu }}}{\text { Jumlah nilai pengujian }}
$$

4. CCME WQI, apabila nilai-nilai faktor telah diperoleh maka dapat dihitung dengan rumus sebagai berikut:

$$
\mathrm{CCME} \text { WQI }=100-\left[\frac{\sqrt{F 1+F 2+F 3}}{1,732}\right]
$$

\begin{tabular}{|c|c|c|c|}
\hline \multirow{2}{*}{$\begin{array}{c}\text { Nilai CCME- } \\
\text { WQI }\end{array}$} & \multicolumn{2}{|c|}{ Kualitas Air } & \multirow{2}{*}{ Rekomendasi } \\
\hline & Tingkat & Kelas & \\
\hline $95-100$ & 1 & $\begin{array}{l}\text { Sangat baik } \\
\text { (Excellent) }\end{array}$ & $\begin{array}{l}\text { Layak untuk media hidup biota perariran dan mendekati } \\
\text { kondisi alamiahnya, dapat dimanfaatkan sebagai sumber } \\
\text { air untuk keperluan apapun, kualitas air terlindungi dan } \\
\text { tidak terdapat gangguan atau ancaman, serta nilai indeks } \\
\text { ini dapat diperoleh bila semua pengukuran baku mutu } \\
\text { memiliki tujuan yang sama sepanjang tahun }\end{array}$ \\
\hline $80-94$ & 2 & Baik $(G o o d)$ & $\begin{array}{l}\text { Layak untuk media hidup biota perairan, diperlukan } \\
\text { pengolahan terlebih dahulu untuk sumber air minum, } \\
\text { terdapat perlindungan kualitas air dan minim ancaman } \\
\text { atau gangguan, serta kondisinya jarang menyimpang } \\
\text { dengan kondisi alamiahnya dan atau peruntukannya }\end{array}$ \\
\hline $65-79$ & 3 & Cukup (Fair) & $\begin{array}{l}\text { Tidak layak untuk sumber air minum namun dalam } \\
\text { kondisi terlindungi, kadang-kadang mengalami gangguan } \\
\text { atau ancaman, serta kadang-kadang kondisinya } \\
\text { menyimpang dari tingkat alamiahnya dan atau } \\
\text { peruntukannya }\end{array}$ \\
\hline $45-64$ & 4 & $\begin{array}{c}\text { Kurang } \\
\text { (Marginal) }\end{array}$ & $\begin{array}{l}\text { Kondisi kualitas airnya sering terancam dan terganggu } \\
\text { serta kondisinya sering menyimpang dari tingkat } \\
\text { alamiahnya dan atau peruntukannya }\end{array}$ \\
\hline $0-44$ & 5 & $\begin{array}{l}\text { Buruk } \\
\text { (Poor) }\end{array}$ & $\begin{array}{l}\text { Kondisi kualitas airnya hampir selalu terancam dan } \\
\text { terganggu serta biasanya kondisinya menyimpang dari } \\
\text { tingkat alamiahnya dan atau peruntukannya }\end{array}$ \\
\hline
\end{tabular}

Tabel 4 Klasifikasi indeks kualitas air CCME WQI

Sumber: Modifikasi dari (Canadian Council of Ministers of the Environment, 2001; Lumb et al., 2011; Kachroud et al., 2019) 


\section{HASIL DAN PEMBAHASAN}

\section{Kualitas Air Sungai Bedadung}

Pada penelitian kualitas air Sungai Bedadung ini menggunakan beberapa parameter fisika, kimia, dan biologi. Hasil pemeriksaan tersebut dapat dilihat pada Tabel 5. Hasil dari pada Tabel 5 merupakan gabungan dari data sekunder pada tahun 2016 sampai dengan 2018 dan data primer pada tahun 2019. Keterbatasan data yang diperoleh dari DLH Jember mengakibatkan ketidakkonsistenan pengambilan data tiap tahunnya dapat dilihat pada Tabel 2, sehingga dibuat data rata-rata per tahun. Merujuk pada tabel tersebut parameter fisika berupa suhu, Total Dissolved Solid (TDS), dan Total Suspended Solid (TSS) dari air Sungai Bedadung pada segmen Kecamatan Patrang, Sumbersari, dan Kaliwates tidak melebihi baku mutu kelas I pada periode pengamatan tahun 2016-2019. Nilai rata-rata suhu, TDS, TSS secara berurutan yaitu $27.40^{\circ} \mathrm{C}, 127.29 \mathrm{mg} / \mathrm{L}$ dan $10.20 \mathrm{mg} / \mathrm{L}$. Suhu memengaruhi jumlah oksigen terlarut, fotosintesis, dan metabolisme biota perairan. Perubahan suhu dan TSS pada perairan dipengaruhi oleh iklim, perubahan vegetasi riparian di bantaran sungai, bahan pencemar dari limbah, dan aktivitas antropogenik (Obade dan Moore, 2018). Secara langsung atau tidak langsung, kondisi parameter fisika seperti suhu dan TSS akan berdampak pada sebaran oksigen pada badan air.

Secara umum fungsi oksigen pada pada air yaitu mendukung fotosintesis dan mereduksi bahan organik. Keberadaan oksigen pada badan air diindikasikan oleh nilai Dissolved Oxygen (DO). Rata-rata nilai DO selama periode pengamatan tahun 2016-2019 sebesar $6.25 \mathrm{mg} / \mathrm{L}$. Akan tetapi nilai DO tersebut tidak memenuhi baku mutu kelas I sebesar $\geq 6 \mathrm{mg} / \mathrm{L}$ pada periode pengamatan Mei 2019. Fluktuasi nilai DO dipengaruhi oleh profil sungai dan jumlah polutan organik. Keberadaan bahan organik di badan air diindikasikan oleh nilai BOD dan COD. Nilai rata-rata BOD dan COD secara berurutan yaitu $5.18 \mathrm{mg} / \mathrm{L}$ dan $15.11 \mathrm{mg} / \mathrm{L}$. Parameter BOD dan COD pada periode pengamatan tahun 2016-2018 tidak memenuhi baku mutu kelas I secara berurutan sebesar $2 \mathrm{mg} / \mathrm{L}$ dan $10 \mathrm{mg} / \mathrm{L}$. Akan tetapi, pada periode pengamatan Mei 2019 nilai kedua parameter memenuhi baku mutu kelas I. Fenomena yang terjadi diasumsikan adanya perbaikan kualitas air Sungai Bedadung yang dipengaruhi oleh kemampuan reduksi polutan organik berdasarkan nilai reoksigenasi yang cukup baik. Laju reoksigenasi di Sungai Bedadung segmen Kecamatan Patrang dan Sumbersari lebih besar dibandingkan nilai deoksigenasinya, sehingga diprediksikan memiliki kemampuan reduksi bahan organik yang cukup baik (Pradana et al., 2019a). Selain itu variasi profil hidrolik sungai dan debit air memiliki peran penting dalam pengenceran nilai COD dan degradasi bahan organik mudah urai (Rahayu et al., 2018). Selain parameter BOD dan COD pada tiga periode pengamatan yang tidak memenuhi baku mutu terdapat parameter kimia lainnya. Parameter tersebut yaitu sulfida, klor, dan fosfat. Nilai baku mutu kelas I dari sulfida $\left(\mathrm{H}_{2} \mathrm{~S}\right)$, klor $\left(\mathrm{Cl}^{-}\right)$, dan fosfat $\left(\mathrm{PO}_{4}\right)$ secara berurutan yaitu $0.002,1$ dan $0.2 \mathrm{mg} / \mathrm{L}$.

Pengamatan kualitas air Sungai Bedadung dilakukan pada lokasi yang sama pada 2016-2019. Lokasi tersebut yaitu Jl Supriyadi, Jl Mastrip, J1 Bengawan Solo, Jl Sumatera, dan Jl Imam Bonjol. Nilai sulfida dalam kurun waktu 3 periode pengamatan yaitu tahun 2016, 2018, dan 2019 tidak memenuhi baku mutu kelas I. Fenomena keberadaan senyawa yang melebihi baku mutu kelas I diasumsikan karena buangan air limbah tanpa pengolahan terlebih dahulu ke Sungai Bedadung dari industri tekstil dan laundry. Berdasarkan kajian lainnya yang dilakukan oleh Supenah et al. (2015), menjelaskan bahwa pembuangan zat warna dari pencucian berpotensi meningkatkan nilai sulfida pada Sungai Condong Kabupaten Cirebon.

Aktivitas domestik dan Perumdam Tirta Pandalungan Kabupaten Jember yang menghasilkan limbah dan berpotensi dialirkan di Sungai Bedadung diasumsikan sebagai penyumbang klor. Adapun sumber pencemaran klor pada badan air diasumsikan berasal dari gas $\mathrm{Cl}_{2}, \mathrm{NaOCl}$, dan $\mathrm{Ca}(\mathrm{OCl})$ atau larutan kaporit. Merujuk pada kajian yang dilakukan oleh Rachmi et al., (2016), menjelaskan bahwa ion klor berasal dari elektrolisis $\mathrm{NaCl}$ yang terlarut dalam air. Fenomena paparan sulfida dan klor yang melebihi ambang batas kelas I pada Sungai Bedadung yang dimanfaatkan sebagai sumber air baku dapat membahayakan kesehatan manusia. 
Tabel 5 Parameter kualitas air Sungai Bedadung tahun 2016-2019 segmen perkotaan Kabupaten Jember

\begin{tabular}{|c|c|c|c|c|c|c|c|c|}
\hline Peubah mutu air & Satuan & $\begin{array}{c}\text { Baku } \\
\text { Mutu } \\
\text { Kelas I }\end{array}$ & 2016 & 2017 & 2018 & 2019 & Rataan & SD \\
\hline Suhu & ${ }^{\circ} \mathrm{C}$ & Deviasi 3 & 30.08 & 27.88 & 26.62 & 25 & 27.4 & 0.64 \\
\hline TDS & $\mathrm{mg} / \mathrm{L}$ & 1000 & 187.8 & 59.23 & 114.115 & 148 & 127.29 & 0.71 \\
\hline TSS & $\mathrm{mg} / \mathrm{L}$ & 50 & 23.6 & 8.9 & 6.9205 & 1.36 & 10.2 & 0.22 \\
\hline $\mathrm{pH}$ & - & $6-9$ & 7.566 & 8.168 & 8.0555 & 8.17 & 7.99 & 0.08 \\
\hline COD & $\mathrm{mg} / \mathrm{L}$ & 10 & 32.116 & 10.868 & 13.383 & 4.08 & 15.11 & 0.93 \\
\hline BOD & $\mathrm{mg} / \mathrm{L}$ & 2 & 10.9 & 4.5 & 4.355 & 0.98 & 5.18 & 0.1 \\
\hline DO & $\mathrm{mg} / \mathrm{L}$ & 6 & 7 & 6.35 & 6.165 & 5.48 & 6.25 & 0.13 \\
\hline $\begin{array}{l}\text { Amonia Bebas } \\
\left(\mathrm{NH}_{3}-\mathrm{N}\right)\end{array}$ & $\mathrm{mg} / \mathrm{L}$ & 0.5 & 0.1504 & 0.00666 & 0.01669 & 0.032 & 0.05 & 0.01 \\
\hline Kobalt (Co) & $\mathrm{mg} / \mathrm{L}$ & 0.2 & 0.001 & 0.08768 & 0.05356 & 0.003 & 0.04 & 0.02 \\
\hline $\operatorname{Kadmium}(\mathrm{Cd})$ & $\mathrm{mg} / \mathrm{L}$ & 0.01 & 0.00112 & 0.01449 & 0.00795 & 0.003 & 0.01 & 0 \\
\hline Tembaga $(\mathrm{Cu})$ & $\mathrm{mg} / \mathrm{L}$ & 0.02 & 0.28778 & 0.0083 & 0.00618 & 0.003 & 0.08 & 0 \\
\hline Seng $(\mathrm{Zn})$ & $\mathrm{mg} / \mathrm{L}$ & 0.05 & 0.01154 & 0.03059 & 0.02125 & 0.0174 & 0.02 & 0.01 \\
\hline Sulfida $\left(\mathrm{H}_{2} \mathrm{~S}\right)$ & $\mathrm{mg} / \mathrm{L}$ & 0.002 & 0.0088 & 0.001 & 0.0123 & 0.0348 & 0.01 & 0.001 \\
\hline Klor $\left(\mathrm{Cl}^{-}\right)$ & $\mathrm{mg} / \mathrm{L}$ & 1 & 5.2724 & 7.106 & 6.537 & 3.14 & 5.51 & 0.4 \\
\hline Sulfat $\left(\mathrm{SO}_{4}\right)$ & $\mathrm{mg} / \mathrm{L}$ & 400 & 12.2502 & 19.79 & 17.825 & 15.58 & 16.36 & 0.42 \\
\hline $\begin{array}{l}\text { Minyak dan } \\
\text { Lemak }\end{array}$ & $\mu \mathrm{g} / \mathrm{L}$ & 1000 & 620 & 320 & 200.0874 & 200 & 335.02 & 0.06 \\
\hline MBAS & $\mu \mathrm{g} / \mathrm{L}$ & 200 & 165.14 & 142.47 & 96.56 & 50 & 113.54 & 0.69 \\
\hline Fenol & $\mathrm{mg} / \mathrm{L}$ & 1 & 0.001 & 0.001 & 0.0014 & 0.002 & 0 & 0 \\
\hline Nitrit $\left(\mathrm{NO}_{2}-\mathrm{N}\right)$ & $\mathrm{mg} / \mathrm{L}$ & 0.06 & 0.1164 & 0.0302 & 0.0323 & 0.004 & 0.05 & 0 \\
\hline Besi $(\mathrm{Fe})$ & $\mathrm{mg} / \mathrm{L}$ & 0.3 & 0.537 & 0.04 & 0.07078 & 0.0984 & 0.19 & 0.02 \\
\hline Timbal $(\mathrm{Pb})$ & $\mathrm{mg} / \mathrm{L}$ & 0.03 & 0.0326 & 0.01655 & 0.00918 & 0.003 & 0.02 & 0.01 \\
\hline Florida (F) & $\mathrm{mg} / \mathrm{L}$ & 0.5 & 0.3657 & 0.023 & 0.6162 & 0.334 & 0.33 & 0.42 \\
\hline $\begin{array}{l}\text { Klorin Bebas } \\
\left(\mathrm{Cl}_{2}\right)\end{array}$ & $\mathrm{mg} / \mathrm{L}$ & 0.03 & 0.2835 & 0.018 & 0.018 & 0.02 & 0.08 & 0 \\
\hline Nitrat $\left(\mathrm{NO}_{3}-\mathrm{N}\right)$ & $\mathrm{mg} / \mathrm{L}$ & 10 & 3.89 & 2.43 & 2.085 & 2.2 & 2.65 & 0.24 \\
\hline Fospat $\left(\mathrm{PO}_{4}\right)$ & $\mathrm{mg} / \mathrm{L}$ & 0.2 & 0.07988 & 0.2045 & 0.25225 & 0.3 & 0.21 & 0.03 \\
\hline Mangan (Mn) & $\mathrm{mg} / \mathrm{L}$ & 1 & 0.1685 & 0.013 & 0.00785 & 0.003 & 0.05 & 0.004 \\
\hline $\begin{array}{l}\text { Kromium } \\
\text { Hexavalen }\end{array}$ & $\mathrm{mg} / \mathrm{L}$ & 0.05 & 0.0232 & 0.022 & 0.0146 & 0.003 & 0.02 & 0.01 \\
\hline Total Coliform & $\begin{array}{c}\text { MPN/ } \\
100 \\
\mathrm{~mL}\end{array}$ & 1000 & 2120 & 386 & 1427 & 1600 & 1383.25 & 0.01 \\
\hline
\end{tabular}

Keberadaan fosfat pada badan air yang melebihi baku mutu juga berpotensi menurunkan kualitas air Sungai Bedadung, selain kandungan sulfida dan klor. Fosfat dalam bentuk ortofosfat pada badan air berfungsi sebagai komponen makronutrien untuk pertumbuhan plankton (Piranti et al., 2018; Marselina dan Burhanudin, 2018). Konsentrasi fosfat yang tinggi pada badan air memicu terjadinya fenomena ledakan pertumbuhan alga sehingga menurunkan kualitas sumber air. Feses manusia, air limbah dari aktivitas mandi dan cuci, serta pupuk dari aktivitas pertanian yang terbawa ke badan air menjadi beberapa penyebab tingginya nilai fosfat tersebut (Marselina dan Burhanudin, 2018). 
Aktivitas mandi, cuci, dan kakus juga diprediksikan memengaruhi paparan mikroorganisme pada Sungai Bedadung. Merujuk pada penelitian yang dilakukan oleh Pradana et al. (2020), peruntukan lahan di Kecamatan Patrang, Sumbersari, dan Kaliwates didominasi oleh pemukiman sehingga paparan bakteri coliform pada Sungai Bedadung relatif tinggi. Total coliform merupakan salah satu indikator keberadaan mikroorganisme pada badan air. Nilai rerata total coliform pada Sungai Bedadung yang melewati wilayah perkotaan Kabupaten Jember pada periode pengamatan tahun 2016-2019. Keberadaan bakteri coliform pada badan air bisa menjadi indikasi keberadaan bakteri patogen seperti $E$. Coli yang berbahaya bagi kesehatan manusia jika dimanfaatkan sebagai sumber air bersih (Piranti et al., 2018).

Kondisi parameter kualitas air Sungai Bedadung beragam. Berdasarkan beberapa periode pengamatan terdapat beberapa parameter yang memenuhi baku mutu kelas I. Adapun persentase parameter yang memenuhi parameter yang tidak melampaui baku mutu kelas I pada periode pengamatan tahun 2016, 2017, 2018, dan 2019. Persentase tersebut mengindikasikan terjadi peningkatan kualitas air Sungai Bedadung di segmen Kecamatan Patrang, Sumbersari, dan Kaliwates.

\section{Daya Tampung Beban Pencemaran}

Penurunan kualitas air sungai dipengaruhi oleh beban pencemaran yang masuk ke sungai. Beban pencemaran memiliki nilai yang beragam pada periode pengamatan Mei 2019 dan dapat dilihat pada Gambar 3a. Adapun nilai beban pencemaran minimum dapat dilihat di grafik pada Gambar 2. Nilai beban pencemaran minimum, yakni yang diperbolehkan sesuai baku mutu, diperoleh dari perkalian konsentrasi BOD, COD, dan TSS sesuai baku mutu kelas I dengan debit air Sungai Bedadung pada setiap lokasi pengamatan.

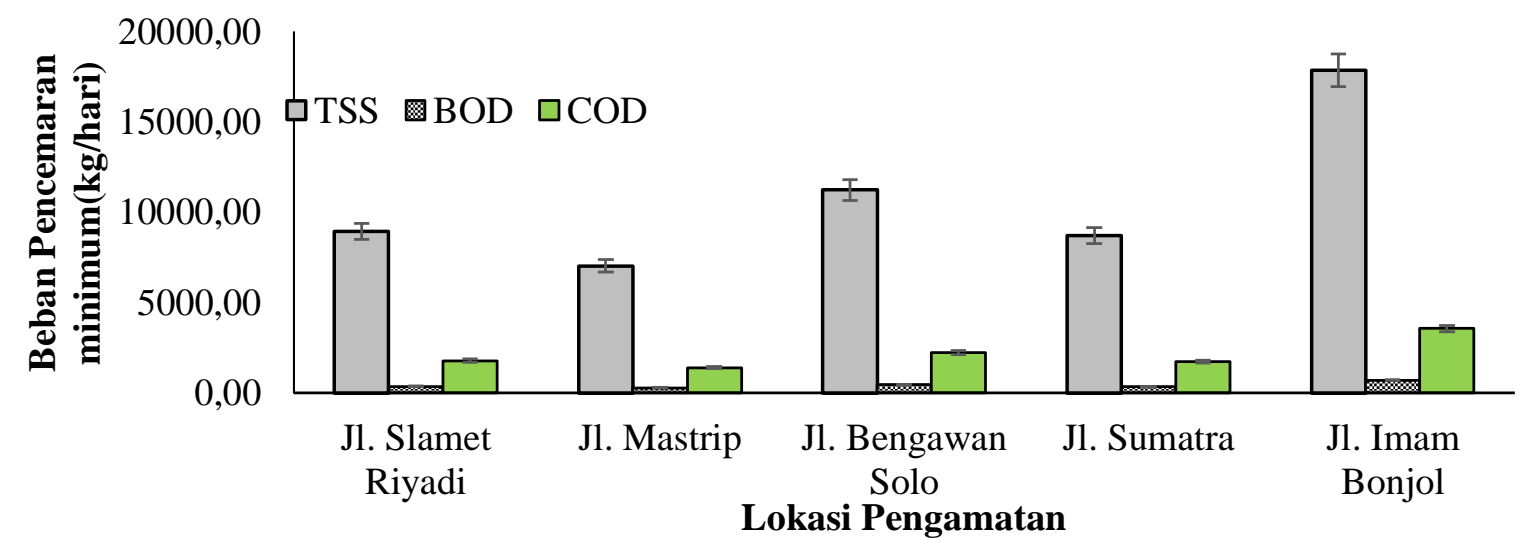

Gambar 2 Nilai beban pencemaran minimum di Sungai Bedadung

Beban pencemaran memiliki nilai yang beragam pada setiap titik pengamatan. Secara umum nilai beban pencemaran terbesar terletak pada lokasi pengambilan contoh air di Jl Imam Bonjol dan menjadi lokasi nilai maksimum beban pencemaran. Nilai beban pencemaran maksimum dari parameter TSS, BOD, dan COD secara berurutan yaitu $428.61 \mathrm{~kg} / \mathrm{hari}, 303.60 \mathrm{~kg} / \mathrm{hari}$ dan $1214.38 \mathrm{~kg} /$ hari. Konsekuensi ini timbul akibat akumulasi debit sungai bernilai $4133.93 \mathrm{~L} / \mathrm{s}$ dan beban pencemaran. Sejalan dengan hal ini laporan dari Pangestu et al. (2017), nilai beban pencemaran pada hilir suatu sungai memiliki nilai yang lebih besar dari pada bagian hulu sungai. Fenomena tersebut terjadi akibat akumulasi debit dan konsentrasi bahan pencemar dari anak sungai atau masukan sumber pencemar. Adapun kajian yang dilakukan oleh Fatmawati et al. (2012) dan Pradana et al. (2019a) menjabarkan bahwa nilai maksimum beban pencemaran terdapat di bagian downstream badan air.

Menurut Djoharam et al. (2018), pengukuran daya tampung beban pencemaran dapat dilakukan berdasarkan selisih antara beban pencemaran minimum dengan beban pencemaran terukur yang dapat dilihat pada persamaan 4. Hasil perhitungan daya tampung beban pencemaran dapat dilihat pada Gambar 3b. Secara umum beban pencemaran berdasarkan parameter TSS, BOD, dan COD tidak melebihi daya tampung beban 
pencemaran karena tidak bernilai negatif pada periode pengamatan Mei 2019. Nilai daya tampung beban pencemaran pada semua lokasi pengamatan tidak mengalami defisit. Daya tampung beban pencemaran terbesar terletak pada Jl Imam Bonjol dengan nilai $17429.99 \mathrm{~kg} / \mathrm{hari}$ TSS, $410.75 \mathrm{~kg} / \mathrm{hari}$ BOD dan 2357.33 $\mathrm{kg} / \mathrm{hari}$ COD. Hal tersebut berarti, agar mencapai baku mutu kelas I berdasarkan parameter TSS, BOD, dan COD dengan fluktuasi debit tertentu, maka beban pencemaran yang diterima oleh Sungai Bedadung tidak boleh melebihi daya tampung beban pencemaran tersebut. Daya tampung beban pencemaran akan berkaitan dengan self purification sungai.

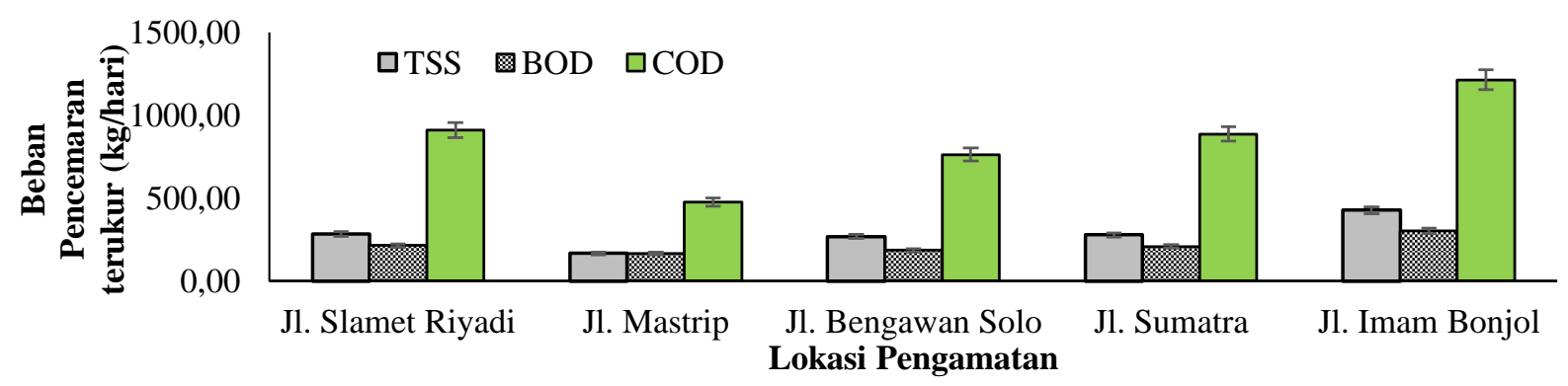

(a) Beban pencemaran terukur pada Sungai Bedadung segmen Perkotaan Kabupaten Jember

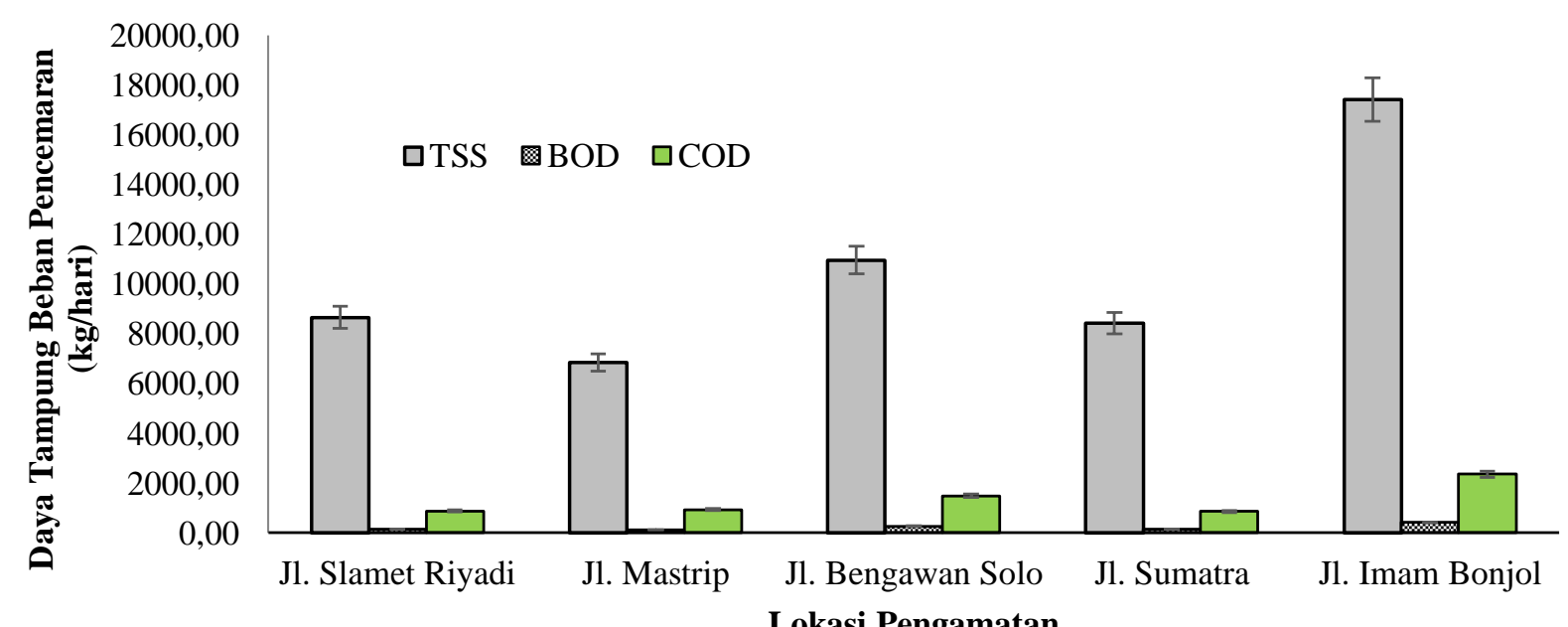

(b) Daya tampung beban pencemaran pada Sungai Bedadung segmen Perkotaan Kabupaten Jember

Gambar 3 Beban pencemaran terukur dan daya tampung beban pencemaran air Sungai Bedadung segmen Perkotaan Kabupaten Jember

Proses alami berupa self purification sungai akan bergantung pada profil hidrolik sungai dan jenis bahan pencemar. Adapun penelitian yang dilakukan oleh Pradana et al. (2019a), melaporkan bahwa Sungai Bedadung utama yang melewati Kecamatan Patrang hingga Sumbersari memiliki kemampuan degradasi bahan organik yang baik berdasarkan laju reoksigenasi dan deoksigenasinya. Meskipun demikian risiko pencemaran akan akan cenderung meningkat akibat pertumbuhan penduduk di DAS Bedadung dan pemanfaatan air Sungai Bedadung. Pencegahan pencemaran sebagai upaya pengelolaan kualitas air harus dilakukan meskipun self purification sungai dalam kondisi baik. Sumber pencemaran dominan berasal dari aktivitas domestik. Konsekuensi ini meningkatkan tekanan pada kualitas air sungai berupa besarnya beban pencemaran yang diterima. Adapun alternatif pengelolan kualitas air yaitu pembuatan IPAL komunal dengan mempertimbangkan lokasi pembangunannya, peningkatan sanitasi lingkungan, perbaikan pengelolaan sampah organik dan anorganik, dan pemantauan kualitas air secara berkala yang melibatkan semua lapisan masyarakat (Marlina et al., 2015; Pohan et al., 2016; Rosiana et al., 2016). 


\section{Indeks Kualitas Air Metode CCME WQI Sungai Bedadung}

Penilaian status mutu air biasnya digunakan untuk menilai kondisi ekosistem perairan dan peruntukannya baik untuk sumber air baku atau lainnya. Status mutu air pada Sungai Bedadung pada wilayah pekotaan Kabupaten Jember dalam kategori tercemar sedang berdasarkan penilaian menggunakan metode indeks pencemaran (Pradana et al., 2020). Penilaian tersebut masih menggunakan data tunggal sehingga kurang merepresentasikan kondisi Sungai Bedadung di segmen perkotaan Kabupaten Jember secara komprehensif jika dilakukan untuk menilai kondisi status mutu air berdasarkan kurun waktu tertentu. Salah satu metode yang cukup baik menggambarkan nilai indeks kualitas air sungai guna mengetahui dampak kebijakan pengelolaan kualitas badan air adalah CCME WQI (Lumb et al., 2011; Kachroud et al., 2019).

Nilai rata-rata indeks kualitas air (IKA) menggunakan metode CCME WQI di Sungai Bedadung pada Gambar 4 sebesar 68.84 dengan kategori cukup (fair). Fluktuasi nilai IKA disebabkan oleh tingginya nilai parameter-parameter pencemar yang melebihi baku mutu kelas I. Parameter yang melebihi baku mutu kelas I dalam tiga sampai dengan empat periode pengamatan yaitu COD, BOD, sulfida $\left(\mathrm{H}_{2} \mathrm{~S}\right)$, klor $\left(\mathrm{Cl}^{-}\right)$, fosfat $\left(\mathrm{PO}_{4}\right)$, dan total coliform. Sumber-sumber dari parameter pencemar tersebut beragam seperti aktivitas domestik, industri, dan pertanian. Sumber pencemaran pada umumnya dipengaruhi oleh tata guna lahan. Merujuk pada penelitian yang dilakukan oleh Pradana et al. (2020), persentase luas lahan pemukiman di Kecamatan Patrang, Sumbersari, dan Kaliwates secara berurutan yaitu 23.54, 30.79 dan 34.56\%. Kencenderungan pemukiman di wilayah tersebut berada di bantaran Sungai Bedadung. Akan tetapi pada periode pengamatan Mei 2019 menujukkan nilai IKA (CCME WQI) mendekati 80. Kondisi tersebut diikuti oleh persentase jumlah parameter kualitas air yang memenuhi baku mutu kelas I lebih baik pada tahun 2019 dengan nilai $82.14 \%$ daripada tahun 2018. Peningkatan nilai tersebut diprediksikan akibat adanya upaya pengendalian pencemaran yang melibatkan partisipasi masyarakat seperti upaya pembersihan Sungai Bedadung dari sampah dan himbauan untuk tidak membuang sampah ke Sungai Bedadung.

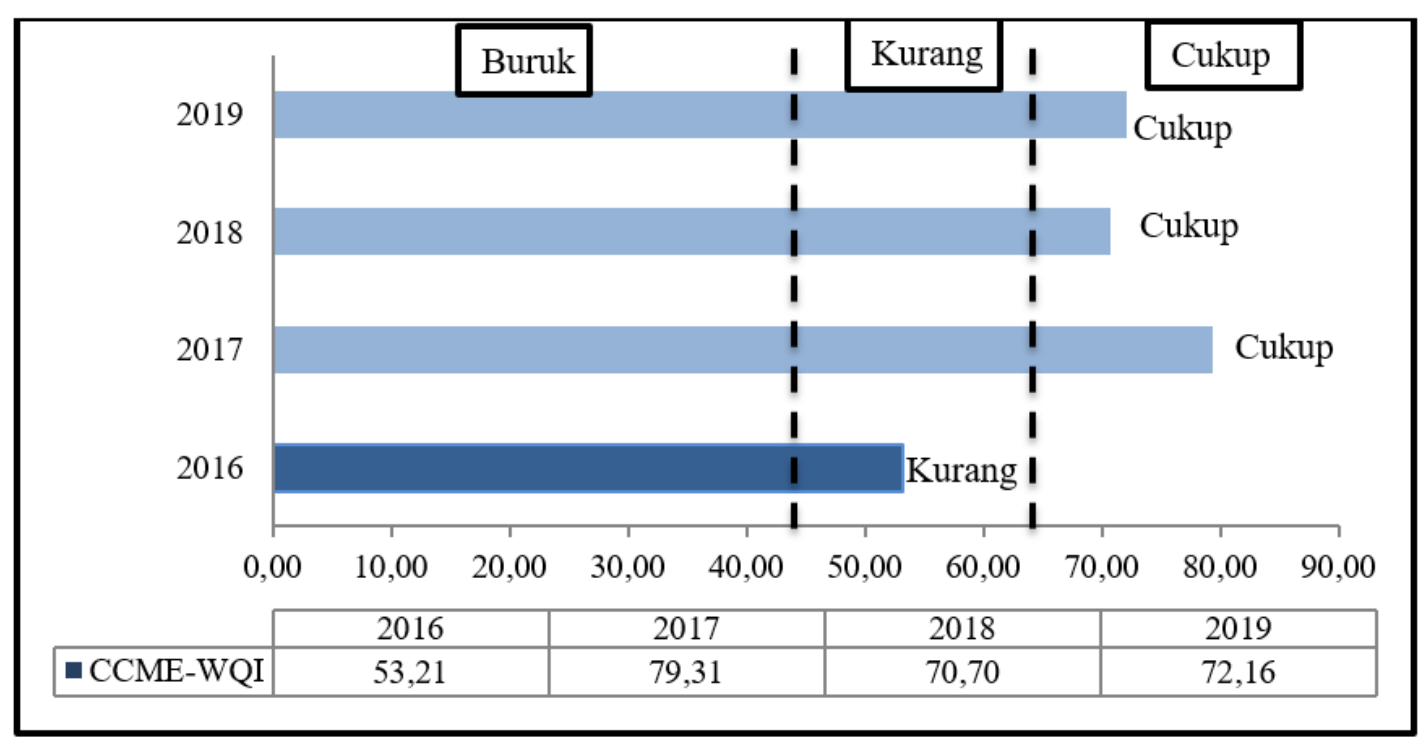

Gambar 4 Indeks kualitas air (CCME WQI) Sungai Bedadung segmen perkotaan Kabupaten Jember

\section{KESIMPULAN}

Penilaian kualitas Air Sungai Bedadung yang melewati Pusat Kegiatan Wilayah atau segmen perkotaan Kabupaten Jember dalam kondisi cukup baik berdasarkan nilai daya tampung beban pencemarannya. Hasil penelitian menunjukkan bahwa nilai daya tampung beban pencemaran Sungai Bedadung berdasarkan parameter TSS, BOD, dan COD secara berurutan yaitu 17429.99 kg/hari, 410.75 kg/hari; dan 2357.33 kg/hari. 
Akan tetapi dari hasil daya tampung beban pencemarannya menunjukkan kondisi kualitas air Sungai Bedadung yang lebih baik dibandingkan evaluasi status mutu air menggunakan indeks kualitas air dengan metode CCME WQI.

Rentang nilai Indeks kualitas air CCME WQI Sungai Bedadung pada segmen Kecamatan Patrang, Sumbersari, dan Kaliwates dari tahun 2016-2019 sebesar 53.21-79.31 dengan kategori cukup (fair) hingga kurang (marginal). Parameter yang mengakibatkan penurunan nilai IKA yaitu $\mathrm{BOD}, \mathrm{COD}, \mathrm{H}_{2} \mathrm{~S}_{1} \mathrm{Cl}^{-}, \mathrm{PO}_{4}$, dan total coliform.

\section{UCAPAN TERIMA KASIH}

Ucapan terima disampaikan kepada Universitas Jember yang telah memberikan dukungan pendanaan pada pelaksanaan penelitian ini dalam Hibah Peneliti Kelompok Riset (KeRis) di Lingkungan Universitas Jember Tahun 2020 berdasarkan SK Rektor Universitas Jember No. 11872/UN25/2020. Segenap tim peneliti dan Civitas Akademika Fakultas Teknologi Pertanian dan Pascasarjana Universitas Jember yang telah memberikan bantuan fasilitas demi kelancaran dan penyelesaian penelitian ini.

\section{DAFTAR PUSTAKA}

[APHA] American Public Health Association, [AWWA] American Water Works Association, [WEF] Water Environment Federation. 2012. Standards Methods for Examination of Water and Wastewater. 22nd Edition. Washington DC (US): American Public Health Association.

[APHA] American Public Health Association, [AWWA] American Water Works Association, [WEF] Water Environment Federation. 2017. Standards Methods for The Examination of Water And Wastewater. 23rd Edition. Washington DC (ID): American Public Health Association.

[Kemeneg LH] Kementerian Negara Lingkungan Hidup. 2003. Keputusan Menteri Negara Lingkungan Hidup Nomor 115 Tahun 2003 tentang Pedoman Penentuan Status Mutu Air. Jakarta (ID): Kemeneg LH.

[PEMDA JEMBER] Pemerintah Daerah Kabupaten Jember. 2015. Peraturan Daerah Kabupaten Jember Nomor 1 Tahun 2015 tantang Rencana Tata Ruang Wilayah (RTRW) Kabupaten Jember Tahun 20152035. Jember (ID): PEMDA JEMBER.

[SNI] Standar Nasional Indonesia Nomor 06-7016-2004. 2004. Tata Cara Pengambilan Contoh dalam rangka Pemantauan Kualitas Air pada Suatu Daerah Pengaliran Sungai. Jakarta (ID): Badan Standardisasi Nasional.

Abbaspour S. 2011. Water quality in developing countries, South Asia, South Africa, water quality management and activities that cause water pollution. International Conference on Environmental and Agriculture Engineering. 15: 94-102.

Asian Development Bank. 2016. Indonesia: Country Water Assessment. Mandaluyong City (PH): Asian Development Bank

Aziza SN, Wahyuningsih S, Novita E. 2018. Beban pencemaran Kali Jompo di Kecamatan Patrang-Kaliwates Kabupaten Jember. J Agroteknologi. 12(1): 100-106.

Canadian Council of Ministers of the Environment. 2001. Candian Water Quality Guidelines for the Protection of Aquatic Life: CCME WQI Quality Index 1. Winnipeg (US): Canadian Council of Ministers of the Environment.

Djoharam V, Riani E, Yani M. 2018. Analisis kualitas air dan daya tampung beban pencemaran sungai pesanggrahan di wilayah provinsi DKI jakarta. Jurnal Pengelolaan Sumberdaya Alam dan Lingkungan. 8(1): 127-133. doi: 10.29244/jpsl.8.1.127-133.

Dwivedi AK. 2017. Reserches in water pollution: a review. International Research Journal Natural Applied Science. 118: 2349-4077. doi: 10.13140/RG.2.2.12094.08002.

Effendi H. 2016. River water quality preliminariy rapid assesment using pollution index. Procedia Environ Sci. 33:562-567. 
Fatmawati R, Masrevaniah A, Solichin. 2012. Kajian identifikasi daya tampung beban pencemaran kali ngrowo dengan menggunakan paket program Qual2Kw. Jurnal Teknik Pengairan. 3(2): 122-131.

Haeruddin H, Febrianto S, Wahyu, Purnomo P. 2019. Beban pencemaran, kapasitas asimilasi dan status pencemaran Estuari Banjir Kanal Barat, Kota Semarang, Jawa Tengah. Jurnal Pengelolaan Sumberdaya Alam dan Lingkungan. 9(3): 723-735. doi: 10.29244/jps1.9.3.723-735.

Hussein S, Ali S. 2017. Water quality index for Al-Gharraf River, southern Iraq. Egypt J Aquat Res. 43(2): 117-122.

Jafarabadi AR, Masoodi M, Sharifiniya M, Bakhtiyari RA. 2016. Integrated river water quality management by CCME WQI as an effective tool to characterize surface water source pollution (case study: Karun River, Iran). Pollution. 2(3): 313-330. doi: 10.7508/pj.2016.03.006.

Kachroud M, Trolard F, Kefi M, Jebari S, Bourrie G. 2019. Water quality indices: challenge and application limits in the literature. Water. 11(361): 1-26. doi: 10.3390/w11020361.

Lumb A, Sharma TC, Bibeault JF. 2011. A review of genesis and evolution of water quality index (WQI) and some future directions. Water Qual Expo Heal. 3: 11-24. doi: 10.1007/s12403-011-0040-0.

Marlina N, Kasam, Juliani A. 2015. Evaluasi daya tampung terhadap beban pencemaran menggunakan model kualitas air (studi kasus: Sungai Winongo). Jurnal Inovasi dan Kewirausahaan. 4(2): 78-86. doi: 10.20885/ajie.vol4.iss2.art2.

Marselina M, Burhanudin M. 2018. Phosphorus load concentration in tropical climates reservoir for each water quantity class. Journal of Water and Land Development. 36(I-III): 99-104. doi: 10.2478/jwld-20180010.

Obade VDP, Moore R. 2018. Synthesizing water quality indicators from standardized geospatial information to remedy water security challenges: a review. Environment International. 119(6): 220-231. doi: 10.1016/j.envint.2018.06.026.

Pangestu R, Riani E, Effendi H. 2017. Estimasi beban pencemaran point source dan limbah domestik di Sungai Kalibaru Timur Provinsi DKI Jakarta. Jurnal Pengelolaan Sumberdaya Alam dan Lingkungan. 7(3): 219-226. doi: 10.29244/jpsl.7.3.219-226.

Pemerintah Indonesia. 2001. Peraturan Pemerintah Republik Indonesia Nomor 82 Tahun 2001 tentang Pengelolaan Kualitas Air dan Pengendalian Pencemaran Air. Jakarta (ID): Sekretariat Negara.

Piranti AS, Rahayu DRUS, Waluyo G. 2018. The Assessment of Rawapening Lake Water Quality Status. $J$ Nat Resour Environ Manag. 8(2): 151-160. doi: 10.29244/jps1.8.2.151-160.

Pohan DAS, Budiyono, Syafrudin. 2016. Analisis kualitas air sungai guna menentukan peruntukan ditinjau dari aspek lingkungan. Jurnal Ilmu Lingkungan. 14(2): 63-71. doi: 10.14710/jil.14.2.63-71.

Poonam T, Tanushree B, Sukalyan C. 2015. Water quality indices-important tool for water quality assesment: a review. Int J Adv Chem. 1(1): 15-29. doi: 10.5121/ijac.2015.1102.

Pradana HA, Novita E, Wahyuningsih S, Pamungkas R. 2019a. Analysis of deoxygenation and reoxygenation rate in the Indonesia River (a case study: Bedadung River East Java). IOP Conf Ser Earth Environ Sci. 243: 1-9. doi: 10.1088/1755-1315/243/1/012006.

Pradana HA, Novita E, Andriyani I, Purnomo BH. 2020. Land use impact to water quality in Bedadung River, Indonesia. IOP Conf. Series: Earth and Environmental Science. 447: 1-7. doi: 10.1088/17551315/477/1/012015.

Pradana HA, Wahyuningsih S, Novita E, Humayro A. 2019b. Identification of the water quality and Pollution Load Bedadung River in water treatment plants intake of Jember Regency Municipal Waterworks. Jurnal Kesehatan Lingkungan Indonesia. 18(82): 135-143. doi: 10.14710/jkli.18.2.135-143.

Rachmi E, Nugrahalia M, Karim A. 2016. Pemeriksaan kualitas air Sungai Sei Kera Medan dengan metode spektrofometri. BioLink. 3(1): 44-55.

Rahayu Y, Juwana I, Marganingrum D. 2018. Kajian perhitungan beban pencemaran air sungai Daerah Aliran Sungai (DAS) Cikapundung dari sektor domestik. Jurnal Rekayasa Hijau. 1(2): 61-71. doi: 10.26760/jrh.v2i1.2043. 
Romdania Y, Herison A, Susilo GA, Novilyansa E. Kajian Penggunaan Metode IP, Storet dan CCME WQI dalam Menentukan Status Kualitas Air. Jurnal Spasial Wahana Komunikasi dan Informasi Geografi. 18(1): 1-13. doi: https://doi.org/10.21009/spatial.182.07.

Rosiana MR, Handayani FS, Qomariah S. 2016. Strategi pengendalian pencemaran air Sungai Pepe. Jurnal Matriks Teknik Sipil. 4(2): 562-569. doi: 10.20961/mateksi.v4i2.37013.

Sahabuddin H, Harisuseso D, Yuliani E. 2014. Analysis of the status of water quality and capacity of pollution of Wanggu River in Kendari City. Jurnal Teknik Pengairan. 5(1): 19-28.

Saraswati SP, Ardion MV, Widodo YH, Hadisusanto S. 2019. Water quality index performance for river pollution control based on better ecological point of view (a case study in Code, Winongo, Gadjah Wong streams). J Civ Eng Forum. 5(1): 47-56. doi: https://doi.org/10.22146/jcef.41165.

Saraswati SP, Sunyoto, Kironoto BA, Hadisusanto S. 2014. Kajian bentuk dan sensitivitas rumus indeks PI, Stroret, dan CCME untuk penentuan status mutu perairan sungai tropis di Indonesia. Jurnal Manusia dan Lingkungan. 21(2): 129-142.

Supenah P, Widyastuti E, Priyono RW. 2015. Kajian kualitas air Sungai Condong yang terkena baungan limbah cair Industri Batik Trusmi Cirebon. Biosfera. 32(2): 110-118. doi: 10.20884/1.mib. 2015.32.2.302.

Tallar RY, Suen J. 2015. Identification of waterbody status in Indonesia by using predictive index assessment tool. Int Soil Water Conserv Res. 3(3): 224-238. doi: 10.1016/j.iswcr.2015.06.009.

Tanika L, Rahayu S, Khasanah N, Dewi S. 2016. Fungsi Hidrologi pada Daerah Aliran Sungai (DAS): Pemahaman, Pemantauan, dan Evaluasi. Bogor (ID): Indonesia World Agroforestry Centre (ICRAF) Southeast Asian Regional Program.

Yetti E, Soedharma D, Haryadi S. 2011. Evaluasi of rivers water quality at Malang upper Brantas River basin area in relation to land use system and its surroundings people activity. J Nat Resour Environ Manag. 1(1): 10-15. doi: 10.19081/jps1.2011.1.1.10.

Yudo S, Said NI. 2018. Water quality status of Ciliwung River in DKI Jakarta region case study: installation of online water quality monitoring station in segment of Kelapa Dua-Istiqlal Mosque. J Teknol Lingkung. 19(1): 13-22. doi: 10.29122/jtl.v19i1.2243.

Yustiani YM, Wahyuni S, Alfian MR. 2018. Investigation on the deoxygenation rate of water of Cimanuk river, Indramayu, Indonesia. Rayasan Journal Chemistry. 11(2): 475-481. 